\title{
INNOVATIVE DEVELOPMENT OF UKRAINE'S ECONOMY: CONCEPTUAL PRINCIPLES AND PROVISIONS OF EFFECTIVE MANAGEMENT
}

\author{
Vladyslav Pavlov ${ }^{1}$ \\ Kyiv National University of Technologies and Design, Ukraine
}

\begin{abstract}
The purpose of the article is to study problems and formulate recommendations for ensuring the formation of the model of the innovation economy in Ukraine and the formation of principles of effective management of the innovative development of the country. Methodology. To achieve these objective, the article used a system of general and special methods of investigation processes and phenomena in their relationship and development, namely, the systematic and structured approach, methods of theoretical analysis and synthesis (for the characteristics of the concepts of "innovation economy", "innovation development" and other related concepts). Thanks to the system-structural approach, innovative economy and innovative development are presented as a set of elements and properties, interactions between them create a new integrity of modern economic relations on a global scale and the scale of a single country (as a part of the global economic environment). Results of the survey showed understanding of the role and place of the "innovative economy" as a concept that characterizes conditions of the interaction of economic entities in the modern economy, with taking into account the peculiarities and priorities of the formation of this economic model in countries with a transition economy. Ukraine, as a country of transition economy, is at an early stage of formation of an effective system of innovative development, and at this stage resolving conflicts of macro-, meso-, and micro-economic interests and objectives in the economic system is an important factor in overcoming the inertia of development. Reference points of the formation and development of innovative economy in Ukraine, with taking into account the experience of today's developed economies should be: high quality of life as a result - its high purchasing power, the ability to buy high-tech products that can be achieved due to the high cost and the quality of human capital; at the same time, the quality of human capital has to be ensured by increasing the level of education and science, which determines the possibility to implement technologies and production mainly in IV-VI technological structure. Practical implications. The stimulation of innovation-oriented development of Ukraine should be based on the creation of a certain form of interaction between the subjects of the economy within the framework of the management system, built on the principles, ideas, and priorities laid down in the concept of "innovative economy". These conditions allow creating an environment within the country, characterized by the redundancy of proposals of innovative solutions and as a result, effective implementation in practice the most productive part of them, due to competition, innovation, ideas, technologies, and processes. Value/originality. Presented instruments of coordination of goals and interests focus on specific, concrete model of development at all levels of the hierarchical subordination of goals and interests through macro, meso, and micro needs establishment, implementation, and wide dissemination of innovation as an essential condition to ensure the competitiveness of enterprises, sectors of the economy at the domestic and foreign markets.
\end{abstract}

Key words: innovative economy, innovation, transitive economy, economic development, competitiveness.

JEL Classification: O11, O3, F63

\section{Introduction}

The urgency of the research. Modern development of the economy and economic scientific thought, as a reflection of the main tendencies of the transformation of socio-economic relations, shows a significant loss of profit position as a classical dominant of explanation of the main goal of economic activity (Aghion, 2015; Ahlstrom, 2010), the majority of modern scholars and practitioners believe that benefits from the activities of economic actors may not only be profitable, but also, in particular, the formation and development of innovation potential and the need for its implementation, which is

Corresponding author:

${ }^{1}$ Department of Economy and Business, Kyiv National University of Technologies and Design.

E-mail: pavlovvt@ukr.net 
conditioned by the rapid development of knowledge and technological innovations (Ahlstrom, 2010).

In view of this, the viewpoint on forms and methods of ensuring economic growth is transforming, from maximizing the benefits to business organizers, to the creation of an innovation-based economy, in which knowledge, technologies, and creativity become priorities of development, which is important not only for business but also (and even more) for consumers of products. So, unlike the supporters of the theory of neoclassical economics, theorists of innovative economy offer different perspectives on the causes of economic growth (Borrás, 2013), i.e. seeing the foundations of economic growth in optimizing the use of knowledge and technology skills, development, implementation, and dissemination of innovations. Growth in the innovation economy, therefore, is the end product of knowledge application (Bohashko, 2013; Borrás, 2016).

Stating the aim of the research. In the modern scientific community of countries with transition economy that inherited resource-oriented economic systems, dependent on market conditions and those which feature in today's global economy may be focused primarily on raw material supply needs of the globalized economy, there is an understanding that traditional, resource-oriented model of economy with limited development potential due to non-renewable natural resources is expedient to transform into a different model, namely the model of "innovation economy".

An alternative to this is isolationist policy, but in the case of transitive economies, transitional nature that determines the direction of development towards the transition to active participation in the international division of labour, this option cannot be regarded as appropriate. For the implementation of "transition" to a model of innovative economy, countries with transition economies should solve several problems of using limited resources, the development of natural and artificial intelligence, the development of effective proportions of material and non-material production, satisfaction of intangible and material needs of society, development, implementation and dissemination of innovation, intellectual property protection. With this in mind, in this article, updated problematic characteristics of conditions and features of innovation-based economic development that significantly associated with the implementation of a model of "innovation economy" in the developed countries as the most effective at this point of the economic basis of socio-economic relations in globalized society.

Actual scientific researches and issues analysis. David Ahlstrom says: "the main purpose of business is to develop new and innovative products and services that generate growth while providing benefits to society" (Aghion, 2015). It should also be noted that, according to leading researchers and economists (Ahlstrom, 2010;
Bohashko, 2013; Borrás, 2016), a source of effective operation and competitiveness in domestic and international markets in terms of innovation economy are more intangible assets (information, knowledge, qualifications and skills of employees, the relationship between them) than material factors of production. In this situation, there is a need to ensure strategic relevance of the macro, meso, and micro level of development of technical and technological basis of modern production and market needs.

Central moment of innovation activity of innovation economics subjects, scholars consider the specific activity of the entity that meets the basic stages of development and innovation processes aimed at creating and making high-quality, fundamental changes in their own system of organization, management, production, etc. (Aghion, 2015). Such an activity is systematic and aimed at implementing innovation through the use of new ideas, knowledge, approaches or transformation of the known research results and practical development of new or improved products (Ahlstrom, 2010).

In modern scholars conceptual positions regarding the innovation economy, science and technologies transform and make a traditional sphere of material production radically change its own technological base, given the fact that innovation is not based on production in the innovation economy is an unsustainable and unnecessary market (Aghion, 2015; Ahlstrom, 2010). The concept of innovation economy is also reflected in the increased variability due to constant innovation technologies (Bohashko, 2013), increased the mobility of industrial structures (Borrás, 2016), strengthening of the internal integration (Borrás, 2013), strengthening global competition (Borrás, 2015).

At the enterprise level, these trends are manifested in virtualization of resources in a global "diversity" of value chains, the concentration of firms in their "key" competencies, and transfer other functions outside contractors, distributing network and virtual organizational forms, spreading the use of creative technologies (Brisbane City Council, 2013; Capello, 2013; Dyer-Witheford, 2014). It is the implementation of similar, innovative economy in countries with economies in transition should become a reference in order to create favourable conditions for the development of these countries. In particular, the issues of innovative development in developing countries and countries with transition economies are studied in (Aghion, 2015; Ahlstrom, 2010; Bohashko, 2013; Edquist, 2015).

Not researched parts of general matters. Instead, systematic studies considering the specifics and trends in countries with transition economy at the moment are still limited and require further development and refinement. Given this, there is a need to adjust traditional views on trends and innovative ways of development of the countries with transition economy in terms of 
distribution of the model of innovation economy on a global scale. Precisely why, the presented research focuses on enriching the scientific understanding of modern economic processes through reflection, theoretical generalization, and structuring issues of innovative economy in the context of innovation-based development as an expedient dominant development in modern conditions of transition economies, giving an individual place to innovative economy in a sense of: 1) the driving force of innovation-based economies of the world in modern conditions; 2) tool to achieve the goals of developing countries with transition economy by economic methods in the conditions of globalization.

As a key driving force of development stands innovation oriented to meet the increasingly growing consumer needs (primarily due to scientific and technical progress) in today's economy.

The research objective. The aim of the article is to study the problems and form recommendations to ensure the establishment of a model of the innovation economy in countries with transition economies in terms of distribution and development of this model in the developed world. Achieving those objectives involves solving problems: 1) analysis of the meaning of "innovation economy" as a phenomenon with certain characteristics and properties; 2) studying the influence of features of social and economic relations in Ukraine as a country with transition economy on innovative development and opportunities for the effective implementation of the model of "innovation economy" in these countries; 3) forming directions for actions at the macro level, contributing to the formation of innovative economy models in countries with transition economies (on the example of Ukraine). Solving these problems is supposed to facilitate the places of the model of the innovative economy as the most important priority of innovation-oriented countries with Ukraine in today's globalized world.

\section{The statement of basic materials.}

\subsection{The problem of creating conditions for the} formation of models of the innovative economy

The history of economic development of recent decades in some countries shows a positive direct connection between the introduction of new technologies and economic growth. Thus, since the end of 1970, according to research (Aghion, 2015), the United States received a disproportionately significant (compared to the share of the population to the world population) share of global wealth, due to the orientation of the implementation of high-tech innovative changes in the market, demonstrating that technological innovation is central catalyst for sustainable economic development at both the individual and specific market economy and the consequent diffusion of innovation of American business around the world - the global economic system and the global market for goods and services.

Another example is that it is the realization of the innovative potential of India and China in 1980-2000 years largely explains the growth of their GDP, helped by the development of national innovation systems of these countries due to significant investments in research and development, as well as the distribution of knowledge and personnel development. Connecting research sector to business and marketing, creating incentives for innovation, balancing imports of technologies and efforts to create their own high-tech development, these two countries had dynamic economic growth in recent decades (Aghion, 2015).

The phenomenon of innovation is inextricably linked with the phenomenon of change, news, ideas or reforms that are traditional in nature but are perceived and presented as new. Innovations are considered to be a variety of facts, processes, and effects of technical, organizational, social or psychological character (Aghion, 2015). The innovation process is the nature of the action, consisting in the occurrence and the first introduction of the new technical, technological, organizational, and other decisions (Ahlstrom, 2010). These actions must, as a result of the cooperation of entities involved in the innovation process, generate some value of the innovation formed due to interaction.

Addressing the problem of creating conditions for the formation of innovative economy models on the example of specific countries - Ukraine, we should analyse trends in innovative development characteristic of the country.

\subsection{The analysis of trends in innovative development}

So, presented in Fig. 1 data on the dynamics of the share of Ukrainian enterprises engaged in innovation in the period of 2000-2015, indicate that the average amount of enterprises engaged in innovation activity in the is $11-18 \%$, this share decreased slightly in the period of 2004-2010, stabilizing after that at $16-17 \%$, so far no significant trend towards an increase (decrease).

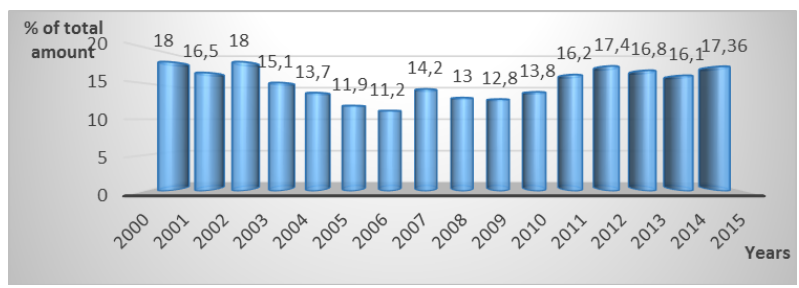

Fig. 1. Change in the share of Ukrainian enterprises, engaged in innovation activity in 2000-2015

Source: based on the State Statistics Committee of Ukraine

Other characteristics that are studied in this paper and should show trends in innovative activity are an implementation of new technological processes (Fig. 2) of industrial enterprises in Ukraine. 
Obvious is a significant reduction in the introduction of innovative products in the first half of the 2000s, after which the indicator stabilized at a level lower than 5000 items. Stable is the level of implementation of new equipment, low-waste, and resource-saving technologies. However, the unstable are dynamics of new processes that, after severe upward trend in 2006-2011, in 2012 received a negative direction of development.

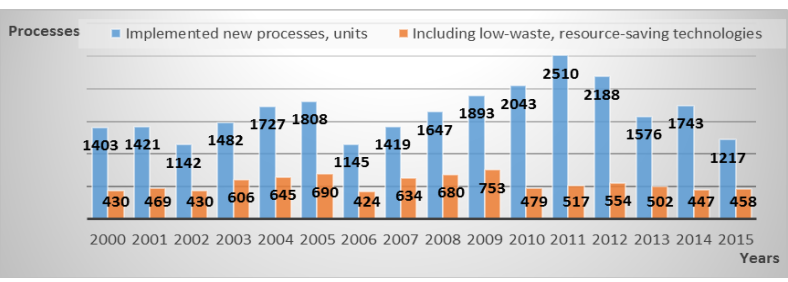

Fig. 2. Implemented new processes of industrial enterprises of Ukraine in 2000-2015

Source: based on the State Statistics Committee of Ukraine

Analysing according to Fig. 3 dynamics of scientific personnel in Ukraine for the 1995-2015 years should be noted a fairly substantial reduction in the number of scientists in the country.

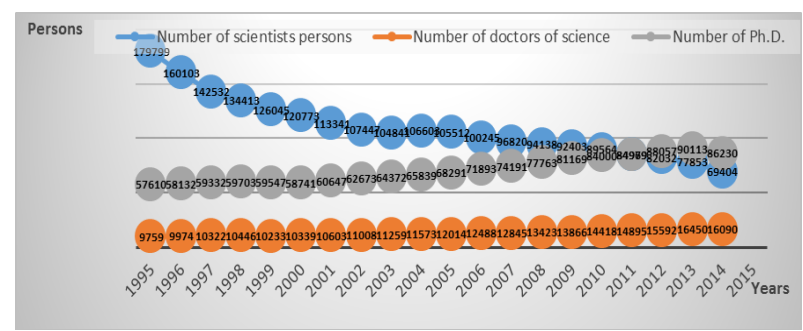

Fig. 3. Research personnel in Ukraine in the 1995-2015 years

Source: based on the State Statistics Committee of Ukraine

So, in 2015 , the number became almost three times less than in 1995, whereas, the number of candidates and doctors in the country increased, which can be explained (in the context of reducing the number of scientists in general) not by improving the quality of science but by the prestige of possession of scientific degrees, often among persons that are directly not related to science (politicians, officials, business representatives).

Somewhat paradoxical is the situation with data of Fig. 3 since 2012, when the number of candidates in the country exceeded the number of scientists, i.e., in the country, having a degree actually ceased to be an indicator of scientists (given that not all scientists are Ph.D.), increasingly focusing on the needs of business and public officials who are not working in scientific institutions without creating a scientific results after upholding a thesis.

However, the more telling indicator is the proportion of scientific and technical work in Ukraine's GDP (Fig. 4), which has a strong tendency to decrease (from $1.36 \%$ in 1996 to $0.64 \%$ in 2015 ). Obviously, the level at $0.6 \%$ of GDP in 2015 is extremely insufficient to consider innovation-oriented country and one that makes efforts to build an innovative economy.

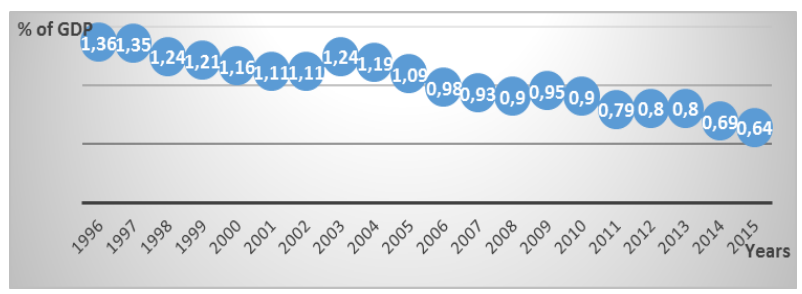

Fig. 4. The proportion of performed scientific and technical work in Ukraine's GDP in 1996-2015

Source: based on the State Statistics Committee of Ukraine

So, we need to consider serious limitations on the innovation process in countries with transition economies. So, based on research experience in Ukraine and the work of other researchers who have studied the problem of innovation in developing countries and countries with transition economies, among factors that complicate the implementation of the innovation process in the mentioned countries, are the following: 1) low level of human resources to work in sectors that are the basis of innovative economy (information technologies, science, education, telecommunications, sphere of innovative services); 2) limited cooperation of the economy with science; 3) limited financing of innovation due to a limited amount of resources available to countries and companies in the state and lack of priority in financing innovation (results from the implementation of which can often be found only in the medium and long term); 4) a small proportion of businesses focused on new technologies; 5) low competence potential of human resources, lack of qualified personnel, ready for productive activities based on the creation and dissemination of knowledge and innovation; 6) limited intra sectorial cooperation and mutually beneficial exchange of "know-how"; 7) limited access to highly specialized consulting services in the field of new technologies, knowledge transfer, and innovation; 8) low motivation and incentives related to individual workers progress in innovation; 9) low level of legal culture in the field of intellectual property.

\subsection{The system of innovative development management of countries with transition economies}

However, the rapid development of new information technologies and the growing flows of information, including audio, video, data, creating communication links, determine the nature of Ukraine's transition from the current situation that is characterized by practical absence of significant recovery tendencies of innovative activity at the macro level, implementation of some innovative projects for individual companies to develop innovative system at the country level as a prerequisite for the success of the economy. This requires more 
resolute replace of the traditional vision of the role and place of Ukraine in the world economy, updating the value of innovation to create sustainable companies in the country position in world markets, to ensure the well-being of the population and its growing influence in modern breakthrough changes in technologies, consumer needs. This vision is expedient to be based on achieving certain benchmarks that are inherent in the innovation economy and create conditions and implement measures to achieve these targets.

Ensure the implementation of initiatives and principles embodied in the concept of an innovative economy will allow the formation of a system of innovative development of the country. This system is an open system of the most important elements to ensure the meaningful progress of the country on the path of innovative development (Fig. 5).

Reference points of the formation and development of innovative economy in Ukraine, with taking into account the experience of today's developed economies should be: high quality of life as a result - its high purchasing power, the ability to buy high-tech products that can be achieved due to the high cost and the quality of human capital; at the same time, the quality of human capital has to be ensured by increasing the level of education and science, which determines the possibility to implement technologies and production mainly in IV-VI technological structure.

These conditions allow creating an environment within the country, characterized by the redundancy of proposals of innovative solutions and as a result, effective implementation in practice the most productive part of them, due to competition, innovation, ideas, technologies, and processes. Indicators of progress towards the creation of an innovative economy of Ukraine should be: increase in the share of innovative enterprises, and as a benchmark for innovative economy - the production of domestically innovative products more than $60-80 \%$ of total production; the high competitiveness of enterprises and the national economy and the effectiveness of marketing activities of these companies in foreign markets, and as a result high economic competitiveness of Ukraine.

\section{Conclusions}

In today's world, the economic base of innovative development at the level of economies of individual countries creates "innovation economy", which should combine the requirements of market rationality of capabilities for creating, widespread introduction, and diffusion of innovation that is the foundation for the growth of consumer needs of the population country and production potential of economic subjects.

Ukraine, as a country of transition economy, is at an early stage of formation of an effective system of innovative development, and at this stage resolving conflicts of macro, meso, and micro-economic interests and objectives in the economic system is an important factor in overcoming the inertia of development. Appropriate instrument of coordination of goals and interests focuses on specific, concrete

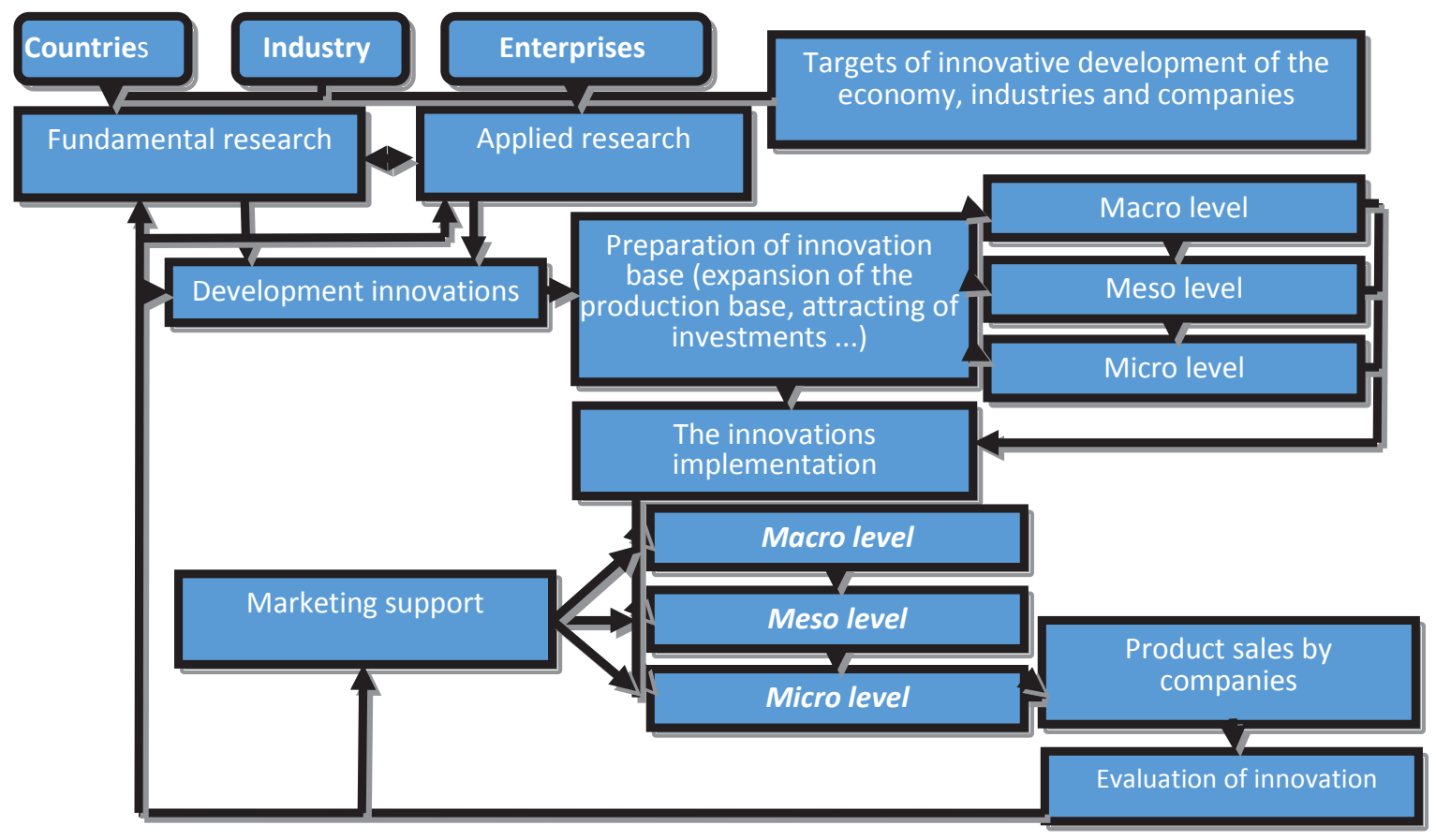

Fig. 5. The system of innovative development management of countries with transition economies

Source: developed by the author 
model of development at all levels of the hierarchical subordination of goals and interests through macro, meso, and micro needs establishment, implementation, and wide dissemination of innovation as an essential condition to ensure the competitiveness of enterprises, sectors of the economy in domestic and foreign markets.

Thus, the formation and development of the innovative economy are advisable to see as the main strategic goal of Ukraine in modern conditions. Progress towards the formation of a similar economic situation in the country will determine the actual possibilities of improving the current state of meso and micro economy, by implementing some of the newest, better than existing, solutions, technologies and ideas in a particular field (economics, marketing, management, technologies, engineering, etc.). It is a key to address expanding market opportunities and strengthening market position at a particular country, industry, and enterprise levels under conditions of purposeful, coordinated at the macro, meso, and micro proactive policy of creating an innovative economy as a model of strategic development of transition economies.

\section{References:}

Aghion P., Akcigit U., \& Howitt P. (2015). Lessons from Schumpeterian growth theory. American Economic Review, no. 105(5), pp. 94-99.

Ahlstrom D. (2010). Innovation and Growth: How Business Contributes to Society. Academy of Management Perspectives, no. 24 (3), pp. 11-24.

Bohashko, O. L. (2013). The evolution of theoretical approaches to innovation development in the economic science. Bulletin of Berdyansk University of Management and Business, vol. 2, no. 22, pp. 23-29.

Borrás S. (2016). Organisations in Innovation Systems: Entrepreneurship, Intrapreneurship and Public Policy. DBP Working Papers. Copenhagen, Department of Business and Politics, Copenhagen Business School. vol. 19.

Borrás S. and C. Edquist. (2013). The Choice of Inovation Policy Instruments. Technological Forecasting and Social Change, no. 80(8), pp.1513-1522

Borrás S. and C. Edquist. (2015). Education, Training and Skills in Innovation Policy. Science and Public Policy, no. 42(2), pp. 215-227.

Brisbane City Council. (2013). Digital Brisbane: A strategy for a digitally driven economy. Available at: http://www.brisbanemarketing.com.au/Business/Digital-Brisbane/pages/Digital-Strategies.aspx

Capello R. and C. Lenzi, Eds. (2013). Territorial Patterns of Innovation. An Inquiry on the Knowledge Economy in European Regions. London, Routledge.

Dyer-Witheford N. (2014). The global worker and the digital front. In C. Fuchs \& M. Sandoval, eds. Critique, social media and the information society. New York: Routledge.

Edquist C. and J. M. Zabala-Iturriagagoitia. (2015). The Innovation Union Scoreboard is flawed: The Case of Sweden - not the innovation leader of the EU. C. W. P. N., vol. 2015/27. 